\title{
“BLUR” AS A WAY OF DEALING WITH MINORITY SHAREHOLDERS
}

\author{
Vlada V. Ozheredova \\ National Research Tomsk State University, Tomsk, Russian Federation \\ Igor S. Bul \\ National Research Tomsk State University, Tomsk, Russian Federation
}

Introduction: the issue of dilution of the minority shareholder's share is relevant for modern Russian corporate law. This is evidenced by the lack of basic research and the emerging jurisprudence on this issue. The paper assesses the draft law, which provides protection of minority shareholders "shares from "blurring", the purpose of the study is to determine what methods are common in practice, as well as to propose ways to solve the problem of blurring the share of shareholders (participants) of economic companies. Methods: the methodological basis of this study is a set of methods of scientific knowledge, among which the main place is occupied by methods of analysis and comparative law. Results: the Work is a reasonable position of the authors, supported by specific simulated situations that reveal the entire essential component of the mechanism of blurring the shareholder's share in the economic society. Such questions as: concept of blur of a share, specificity of this phenomenon, and distinctive features are revealed. Conclusions: the study identified options for majority (large) shareholders in relation to minority shareholders on the issue of dilution of the share, and infringement of the rights of minority shareholders in the field of corporate governance.

Key words: corporate law, shares, shares, shareholder, participant, majority, minority, dilution of shares.

Citation. Ozheredova V.V., Bul I.S. "Blur" as a Way of Dealing with Minority Shareholders. Legal Concept, 2019, vol. 18, no. 2, pp. 112-116. (in Russian). DOI: https://doi.org/10.15688/lc.jvolsu.2019.2.18

\section{«РАЗМЫТИЕ» ДОЛИ КАК СПОСОБ БОРЬБЫ С МИНОРИТАРНЫМИ АКЦИОНЕРАМИ}

\section{Влада Васильевна Ожередова}

Национальный исследовательский Томский государственный университет, г. Томск, Российская Федерация

\section{Игорь Сергеевич Буль}

Национальный исследовательский Томский государственный университет, г. Томск, Российская Федерация

Введение: вопрос размытия доли миноритарного акционера актуален для современного российского корпоративного права. Об этом свидетельствует отсутствие фундаментальных исследований и складывающаяся судебная практика по данному вопросу. В работе дается оценка законопроекту, который обеспечивает защиту долей миноритарных акционеров от «размытия», цель исследования - определить, какие способы являются часто встречающимися на практике, а также предложить пути решения проблемы размытия доли акционеров (участников) хозяйственных обществ. Методы: методологическую основу данного исследования составляет совокупность методов научного познания, среди которых основное место занимают методы, анализа и сравнительно-правовой. Результаты: работа представляет собой обоснованную позицию авторов, подкрепленную конкретными смоделированными ситуациями, которые раскрывают всю сущностную составляющую механизма размытия доли акционера в хозяйственном обществе. Раскрываются такие вопросы, как: понятие размытия доли, специфика этого явления и отличительные черты. Выводы: в результате 
B.В. Ожередова, И.С. Буль. «Размытие» доли как способ борьбы с миноритарными акционерами

исследования определены варианты действий мажоритарных (крупных) акционеров по отношению к миноритарным акционерам по вопросу размытия доли и ущемлению прав миноритариев в сфере корпоративного управления.

Ключевые слова: корпоративное право, акции, доли, акционер, участник, мажоритарий, миноритарий, размытие доли.

Цитирование. Ожередова В. В., Буль И. С. «Размытие» доли как способ борьбы с миноритарными акционерами // Legal Concept = Правовая парадигма. - 2019. - T. 18, № 2. - C. 112-116. - DOI: https://doi.org/ 10.15688/lc.jvolsu.2019.2.18

\section{Введение}

Экономические отношения включают в себя несколько составляющих, одной из которых является деятельность хозяйственных обществ. В связи с этим для нормального функционирования необходимо обеспечение соблюдения прав участников рассматриваемых отношений. В работе рассмотрен вопрос, касающийся неясности понятия «размытие» доли, приведены конкретные примеры, с изменением лиц и ситуаций, когда на практике происходит «размытие» доли. Кроме этого, в работе рассмотрен законопроект, который в 2017 г. поступил на рассмотрение в Государственную Думу РФ. Проект Федерального закона № 229418-7 «О внесении изменений в статьи 40 и 75 Федерального закона «Об акционерных обществах» (далее - законопроект) преследует цель, в первую очередь - защитить права миноритариев - владельцев обыкновенных акций от «размытия» их доли в уставном капитале акционерного общества, путем размещения привилегированных акций. По мнению разработчиков законопроекта, закрепление критерия средневзвешенной цены за определенный период позволит предлагать акционерам цену выкупа, в большей степени отвечающую стоимости принадлежащих им акций.

\section{К вопросу о сущности «размытия» доли миноритарного акционера, как явления в корпоративном праве}

Подавляющее число корпораций включает в себя зачастую одного контролирующего акционера и небольшое число блокирующих держателей акций.

Мажоритарные акционеры, обладая подавляющим процентом акций компании, фактически обеспечивают принятие любого, выгодного для себя решения по результатам общего собрания акционеров. Однако миноритарные акционеры в определенных случаях могут заблокировать реализацию ряда решений, принятых на общем собрании. «Размытие» доли миноритарного акционера - термин, используемый в области корпоративного права. С данным явлением сталкиваются в первую очередь при увеличении уставного капитала путем размещения дополнительных акций. Необходимо отметить, что наиболее подвержены «размыву» доли акционеров в следующих случаях:

- при размещении дополнительных акций посредством закрытой подписки;

- при размещении посредством открытой подписки дополнительных обыкновенных акций.

Цели, которые преследует корпорация для размещения дополнительных акций, могут быть весьма разные. В первую очередь увеличение уставного капитала, но не следует забывать о том, что с помощью этого способа мажоритарные акционеры могут перераспределить контроль на общем собрании акционеров.

Судебная практика обратила внимание на этот вопрос, и Президиум ВАС РФ своим постановлением от 06.04.2010 № 17536/09 по делу № A51-11603/200844-328 указал, что увеличение уставного капитала с единственным намерением перераспределить голоса на общем собрании акционеров, не соответствует законным целям размещения дополнительных акций, что является достаточным поводом для подачи иска миноритарными акционерами.

Об этом могут свидетельствовать следующие обстоятельства:

- цена размещения акций не соответствует их рыночной стоимости;

- экономически обоснованная необходимость у общества в привлечении дополнительных средств путем эмиссии отсутствует; 
- в результате размещения акций общество привлекает незначительный объем дополнительных средств. Это подтверждает и судебная практика: постановление ФАС Западно-Сибирского округа от 16.09.2013 по делу № A27-8268/2012, Северо-Кавказского округа от 24.04.2012 по делу № А63-5890/2011, Девятого арбитражного апелляционного суда от 30.10.2013 по делу № A40-105271/2012.

В связи с этим мажоритарным акционерам необходимо для минимизации рисков получать отчеты о независимой оценке рыночной стоимости размещаемых акций, а также готовить финансово-экономическое обоснование привлекаемых в результате эмиссии средств.

Что же следует понимать под размытием доли миноритарного акционера? Так, А. Глушецкий не рассматривает отдельно такое явление, как размытие доли, а целиком относит это к понятию «размывание корпоративного контроля», под которым понимает установление инвестиционных корпоративных прав независимо от размера доли участника в уставном капитале и (или) увеличение статусных корпоративных прав за счет сокращения инвестиционных [3, с. 70]. Наиболее часто встречающееся определение размытия доли выглядит следующим образом - это уменьшение доли относительно увеличившегося уставного капитала организации при одновременном сохранении ее номинальной стоимости или при непропорциональном увеличении номинальной стоимости доли относительно увеличения уставного капитала [1, с. 71].

\section{Механизм «размытия» доли в хозяйственном обществе}

На практике механизм по «размытию» доли выглядит следующим образом: два физических лица - Буль и Извеков решили создать общество с ограниченной ответственностью на равных началах, то есть $50 \%$ доли у каждого, при этом уставной капитал они определили в размере 10000 рублей, или $100 \%$. После регистрации юридического лица как такового каждому из них принадлежит равная доля в $50 \%$, или же 5000 рублей относительно уставного капитала.
По прошествии года перед ООО встала необходимость в получении лицензии на торговлю спиртосодержащей продукции. Для данной лицензии требуется минимальный уставной капитал 1000000 рублей. Узнав об этом, Буль сообщил Извекову, что ничего не может вложить, так как у него нет дополнительных денежных средств, а Извеков смог вложить только 485000 рублей. Они решили привлечь Зайцева, который вложил недостающие 505000 рублей.

В итоге получилась следующая ситуация: уставной капитал ООО увеличился с 10000 до 1000 000, и теперь составил $100 \%$. Доля Зайцева относительно установившегося уставного капитала составила 505000 $50,5 \%$, доля Извекова, хотя и увеличилась с 5000 до 490 000, но относительно нового размера составила лишь $49 \%$, а доля Буль составила $0,5 \%$ вместо прежних $50 \%$.

Из данного примера следует, что доли первоначальных участников, то есть Извекова и Буль были размыты. Доля Извекова была размыта не столь ощутимо - с 50 до $49 \%$, а доля Буль - с 50 до 0,5\%.

Другой пример. Акционерное общество «Буль и команда». При создании общества было выпущено 1000 акций, рыночная стоимость одной составила 1000 рублей. Соответственно капитализация АО - 1000000 рублей. Извеков как акционер имеет 100 акций АО «Буль и команда», и его доля составляет $10 \%$.

Спустя полгода активной работы $\mathrm{AO}$ «Буль и команда» принимают программу развития, которая требует дополнительных средств в размере 400000 рублей. Акционерное общество находит самый оптимальный из возможных способов финансирования - это дополнительная эмиссия акций. В выкупе акций уже заинтересованы крупные акционеры, имеющие свободные денежные средства. Извеков тоже имеет право на выкуп части акций, пропорциональной доли, однако свободных денежных средств для выкупа у него нет. В связи с этим Извеков на общем собрании голосует против такого способа привлечения капитала, однако решение все же принимается большинством голосов.

По результатам эмиссии количество акций увеличивается с 1000 до 1400 штук. В связи с этим у тех, кто выкупил акции, доля 
B.В. Ожередова, И.С. Буль. «Размытие» доли как способ борьбы с миноритарными акционерами

в АО «Буль и команда» выросла, а доля Извекова соответственно сократилась с 10 до $7,2 \%$. Не заставили себя ждать и последствия дополнительной эмиссии акций - на очередных перевыборах Извеков потерял место в Совете директоров.

Как итог - доля Извекова в АО «Буль и команда» была «размыта».

\section{Способы защиты миноритарных акционеров от «размытия» доли}

Возникает вполне резонный вопрос: какие способы защиты в рамках правового поля имеет миноритарный акционер? Каким образом он может восстановить корпоративный контроль?

Одним из способов, к которому чаще всего прибегают миноритарии на практике, является оспаривание решения совета директоров или общего собрания акционеров, которыми была инициирована и реализована процедура дополнительной эмиссии акций. Согласно Федерального закона от 26.12.1995 № 208 «Об акционерных обществах», где в статьях 49 и 68 указано: акционер имеет право обжаловать в суд решение соответствующего органа управления обществом, если принятое этим органом решение нарушает, или иным образом затрагивает права и законные интересы акционера или общества [4, с. 43].

В 2017 г. в Государственную Думу РФ был внесен проект Федерального закона № 229418-7 «О внесении изменений в статьи 40 и 75 Федерального закона “Об акционерных обществах”» (далее - законопроект). Целью данного законопроекта в первую очередь является защита прав миноритариев владельцев обыкновенных акций от «размытия» их дивидендных прав и доли в уставном капитале акционерного общества путем размещения привилегированных акций. Действующие положения Федерального закона от 26.12.1995 № 208-Ф3 «Об акционерных обществах» (далее - Закон об АО) предоставляют владельцам акций преимущественное право приобретения вновь размещаемых акций лишь соответствующей категории (типа) [5, c. 2]. При этом преимущественное право приобретения не распространяется на акции иной категории (типа). В результате такого регулирования существует риск нарушения интересов миноритарных акционеров при размещении акций иной категории. По мнению разработчиков законопроекта, закрепление критерия средневзвешенной цены за определенный период позволит предлагать акционерам цену выкупа, в большей степени отвечающую стоимости принадлежащих им акций $[2$, с. 7$]$.

\section{Выводы}

Подводя итог, необходимо вновь обратить внимание на ключевые аспекты. Вопрос, касающийся размытия доли, является проблемным по ряду причин: во-первых, это отсутствие легального определения и единства понимания такого явления, как «размытие» доли. Во-вторых, это недостаточность правового регулирования механизма противодействия «размытию» доли в корпоративном законодательстве. В-третьих, это развитие и использование противоправных способов под видом законных, что порождает за собой вторую проблему. В связи с этим предложения по защите прав миноритарных акционеров в сфере вопросов по «размытию» долей должны быть учтены законодателем.

\section{СПИСОК ЛИТЕРАТУРЫ}

1. Адамович, Г. Л. Проблемы применения института злоупотребления правом в акционерных правоотношениях / Г. Л. Адамович // Хозяйство и право. - 2005. - № 5. - С. 71-75.

2. Ворожевич, А. Участник с 99-процентной долей вышел из общества. Как оставшемуся участнику уменьшить уставный капитал? / А. Ворожевич // Экономика и жизнь. Юрист, приложение «Ваш партнер-консультант». - 2017. - № 29 (9695).

3. Глушецкий, А. Размывание корпоративного контроля и ограничения его концентрации / А. Глушецкий // Корпоративные стратегии. 2012. - № 50 (9466). - С. 69-74.

4. Федеральный закон «Об акционерных обществах» от 26.12.1995 № 208-ФЗ. - Доступ из справ. правовой системы «КонсультантПлюс».

5. RusЮрист : онлайн-журнал для юристов. Электрон. дан. - Режим доступа: https://rusjurist.ru. 


\section{ВОПРОСЫ ЧАСТНОПРАВОВОГО РЕГУЛИРОВАНИЯ}

\section{REFERENCES}

1. Adamovich G.L. Problems of Application of the Institute of Abuse of Law in Joint-Stock Relations. Economy and Law, 2005, no. 5, pp. 71-75. (in Russian).

2. Vorozhevich A. The Participant with a $99 \%$ Share Left the Company. How can the Remaining Participant Reduce the Authorized Capital? Journal "Your PartnerConsultant”EJ Lawyer, 2017, no. 29 (9695) (in Russian).
3. Glushetskiy A. The Dilution of Corporate Control and Restriction of its Concentration. Corporate Strategies, 2012, no. 50 (9466), pp. 69-74. (in Russian).

4. Federal Law "On Joint Stock Companies" of 26.12.1995 № 208-FZ. ConsultantPlus: reference. legal system. Prof Version.

5. Rus Lawyer: Online Magazine. URL: https: //rusjurist.ru.

\section{Information about the Authors}

Vlada V. Ozheredova, Senior Lecturer, Department of Civil Procedure, Law Institute, National Research Tomsk State University, Moskovsky Trakt St., 8, 634000 Tomsk, Russian Federation, vlada.ogeredova@mail.ru, https://orcid.org/0000-0003-0889-3686

Igor S. Bul, Master Student, Law Institute, National Research Tomsk State University, Moskovsky Trakt St., 8, 634000 Tomsk, Russian Federation, igor-bu197@mail.ru, https://orcid.org/0000-0002-3846-9598

\section{Информация об авторах}

Влада Васильевна Ожередова, старший преподаватель кафедры гражданского процесса Юридического института, Национальный исследовательский Томский государственный университет, ул. Московский тракт, 8, 634000 г. Томск, Российская Федерация, vlada.ogeredova@mail.ru, https://orcid.org/0000-0003-0889-3686

Игорь Сергеевич Буль, магистрант I курса Юридического института, Национальный исследовательский Томский государственный университет, ул. Московский тракт, 8, 634000 г. Томск, Российская Федерация, igor-bu197@mail.ru, https://orcid.org/0000-0002-3846-9598 